\title{
Polish version of the Hospital Survey on Patient Safety Culture
}

\section{Polska wersja kwestionariusza Hospital Survey on Patient Safety Culture}

\author{
Rafał Szpakowski ${ }^{A-F}$ \\ Department of Public Health, Faculty of Health Sciences, Medical University of Warsaw, Poland \\ A - research concept and design; $B$ - collection and/or assembly of data; $C$ - data analysis and interpretation; \\ $D$ - writing the article; $E$ - critical revision of the article; $F$ - final approval of the article
}

Pielęgniarstwo i Zdrowie Publiczne, ISSN 2082-9876 (print), ISSN 2451-1870 (online)

Piel Zdr Publ. 2019;9(3):159-166

\section{Address for correspondence \\ Rafał Szpakowski \\ E-mail: rafszpakowski@gmail.com \\ Funding sources \\ None declared \\ Conflict of interest \\ None declared}

Received on September 15, 2017

Reviewed on November 3, 2017

Accepted on February 20, 2019

\section{Cite as}

Szpakowski R. Polish version of the Hospital Survey on Patient Safety Culture. Piel Zdr Publ. 2019;9(3):159-166. doi:10.17219/pzp/104607

DOI

10.17219/pzp/104607

\section{Copyright}

(C) 2019 by Wroclaw Medical University

This is an article distributed under the terms of the

Creative Commons Attribution Non-Commercial License

(http://creativecommons.org/licenses/by-nc-nd/4.0/)

\begin{abstract}
Background. Assessments of patient safety culture at healthcare institutions such as hospitals usually include a survey of staff perceptions. There are several tools to measure subjective opinions of patient safety in hospitals.
\end{abstract}

Objectives. This pilot study was designed to test the feasibility of adapting the Agency for Healthcare Research and Quality (AHRQ) Hospital Survey on Patient Safety Culture (HSOPSC) to the context of the Polish healthcare system.

Material and methods. The study was conducted at a multi-site public hospital located in the Mazovian voivodeship of Poland, in a district (powiat) with a population of over 70,000. The hospital has a total capacity of 199 beds on 9 wards. A paper-based Polish translation of the HSOPSC (Ankieta Szpitalna Bezpieczeństwa Pacjenta - ASBP) was personally distributed among the nursing/midwifery staff between May 20 and June 5, 2015.

Results. None of the 103 respondents commented in any way on the correctness of the form of the questions. Also, the response rate (RR) was high (88\%). Among the respondents, 39.2\% ( $n=40)$ gave their work unit a global safety grade of "acceptable", while 54.9\% ( $n=56)$ graded it "very good". The majority of the respondents $(80.1 \% ; n=81)$ had not reported any unsafe event in the previous 12 months. Cronbach's a scores ranged from 0.37 to 0.89 . Only 4 dimensions received reliability scores above 0.70 .

Conclusions. The Polish-language version of the HSOPSC is less psychometrically sound than the original and many other European versions. This pilot study provided evidence that the logical and grammatical construction of the translated questions enable the Polish-language version of the HSOPSC to be used on a larger population of health workers in Poland in order to fully assess psychometric properties of this questionnaire.

Key words: nurse, patient safety, healthcare quality, hospital 


\section{Streszczenie}

Wprowadzenie. Ocena kultury bezpieczeństwa pacjenta w podmiotach ochrony zdrowia, takich jak szpital, zazwyczaj obejmuje badanie percepcji personelu. Istnieje kilka narzędzi służących do pomiaru subiektywnej opinii na temat bezpieczeństwa pacjenta w szpitalu.

Cel pracy. Niniejsze badanie pilotażowe zostało zaprojektowane w celu sprawdzenia przydatności ankiety Hospital Survey on Patient Safety Culture (HSPOSC) stworzonej przez Agency for Healthcare Research and Quality (AHRQ) w kontekście polskiego systemu opieki zdrowotnej.

Materiał i metody. Badanie zostało przeprowadzone w wieloprofilowym szpitalu publicznym w Polsce, w województwie mazowieckim, w powiecie liczącym >70 tys. mieszkańców. Szpital posiada 199 łóżek na 9 oddziałach. Kwestionariusz papierowy ankiety polskiej wersji HSPOSC (Ankiety Szpitalnej Bezpieczeństwa Pacjenta - ASBP) był osobiście wręczany pielęgniarkom i położnym zatrudnionym w okresie 20.05.2015 r. - 5.06.2015 r.

Wyniki. Żadna ze 103 respondentek nie miała uwag odnośnie do poprawności treści pytań. Stopień realizacji próby (RR) był wysoki (88\%). Wśród badanych 39,2\% ( $n=40)$ oceniło ogólne bezpieczeństwo pacjenta na swoim oddziale jako akceptowalne, a 54,9\% ( $n=56)$ - jako bardzo dobre. Większość badanych (80,1\%; $n=81$ ) nie raportowała żadnych zdarzeń niepożądanych w ostatnich 12 miesiącach. Wskaźnik rzetelności a Cronbacha zawierał się w przedziale 0,37-0,89. Tylko 4 wymiary uzyskały wskaźnik rzetelności >0,70.

Wnioski. Polska wersja ankiety HSPOSC wypadła gorzej pod względem psychometrycznym niż wersja oryginalna oraz wiele innych wersji europejskich. Niniejsze badanie pilotażowe dostarczyło dowodów na poprawność gramatyczną i logiczną przetłumaczonych pytań, co umożliwia użycie polskiej wersji HSOPSC na większej populacji pracowników medycznych w Polsce w celu pełnej oceny psychometrycznej.

Słowa kluczowe: pielęgniarka, bezpieczeństwo pacjenta, jakość w ochronie zdrowia, szpital

\section{Background}

Assessments of patient safety culture at healthcare institutions such as hospitals usually include a survey of staff perceptions. There are several tools to measure subjective opinion of patient safety in hospitals. These tools differ in the aspects measured, but there are principal factors repeated in every version of the tools: leadership, communication, reporting of incidents, safety policies, and procedures. ${ }^{1,2}$ The question of which tool measures patient safety in a reliable way has been the subject of many scientific studies. Based on an analysis of literature, the current author chose the Hospital Survey on Patient Safety Culture (HSOPSC), created by the Agency for Healthcare Research and Quality (AHRQ), as it is the best-known tool used worldwide to measure the culture of patient safety. This tool has been used in many language contexts and cultures, which makes it ideal for comparisons. ${ }^{2}$ This pilot study was designed to test the feasibility of adapting this tool to the context of the Polish healthcare system.

The aim of the study was to test a Polish-language version (Ankieta Szpitalna Bezpieczeństwa Pacjenta - ASBP) of the HSOPSC in terms of the intelligibility of the HSOPSC questions translated into Polish, to assess the willingness of respondents to fill out and return the ASBP questionnaire (response rate), and also to explore construct validity to some extent.

\section{Material and methods}

The author wanted to assess the psychometric properties of the ASBP, but did not succeed because the sample size was too small. ${ }^{1}$ There are many reasons for a pilot study, ${ }^{3}$ but from the author's methodological point of view, the most important aim in this case was to check the correctness of the translation of the questions and the respondents' ability to understand their meaning. For this purpose, when the author distributed the questionnaires, he asked the respondents to share any doubts they had about the questions in a special section at the end of the survey.

A less important but also essential reason to perform this pilot study was to learn about the response rate (RR) of the ASBP, which allows somewhat greater precision in determining the number of distributed questionnaires required to achieve an appropriate sample size in the main study analyzing the psychometric properties of the ASBP. The response rate may indirectly provide information about whether the questionnaire is difficult for the respondents or not. It is obvious that it is not only the complexity of the survey that affects the response rate; if the survey met the other criteria for a high response rate but was highly complicated and unintelligible to the respondents, achieving a high response rate would be impossible. ${ }^{4}$ It is therefore worth checking the response rate, because if a low response rate results from unclear questions, the transparency of meaning of the questions needs to be improved.

The study was conducted at a multi-site public hospital located in the Mazovian voivodeship of Poland, in a district (powiat) with a population of over 70,000. The hospital has a total capacity of 199 beds and 9 wards. A paper-based ASBP survey was personally distributed among the nursing/midwifery staff between May 20 and June 5, 2015. The author distributed 117 questionnaires to all the employed nursing/midwifery staff. The HSOPSC 
survey had been translated into Polish with no modification of any of the items. The 42 -item structure with a 5-point agreement or frequency scale was preserved; the 2 single-item outcome variables, i.e., "Global safety grade" and "Number of incidents reported in the past year", were also preserved. ${ }^{5}$

Descriptive statistics were reported - means and standard deviation for 1-5 scale, missing values, proportion of positive responses for qualitative scale (e.g., agree and strongly agree); characteristics of respondents; and basic statistical analysis concerning, firstly, the construct validity - mean scores of 10 process dimensions defined by the 2 single-item outcome variables - "Patient safety grade" and "Number of incidents reported". These 2 outcome variables were divided into 2 groups - "excellent/very good" vs the rest, and "Incident reported one or more" vs "None incidents reported". The differences between score means were tested with Student $t$ test. Secondly, concerning correlation between positive score percent and mean score using Pearson's r correlation coefficient. Thirdly, concerning internal consistency reliability - Cronbach's $\alpha$ (acceptable reliability at 0.70 or more). ${ }^{5}$ The methodology applied for calculating positive responses was identical to the methodology used by the AHRQ. ${ }^{6}$ The level of statistical significance was set at $p \leq 0.05$.

\section{Results}

None of the 103 respondents commented in any way on the correctness of the form of the questions (Table 1). The RR was high (88\%). Most of the 103 respondents had worked more than 21 years at the hospital considered in the study, and half of them had worked more than 21 years in their current ward/unit. Almost half of the respondents $(n=48)$ worked $20-39$ h per week; the same number worked 40-59 h per week. More than half of the 103 respondents had a university education, while $32 \%$ had nursing-school diplomas. More than $90 \%$ of the respondents had direct interaction or contact with patients. The majority of the respondents (82\%) had worked as a nurse/midwife more than 21 years (Table 2). Most of the respondents worked on interventional wards/units - i.e., obstetrics, surgery and the ICU (Table 3).

Only 1 respondent gave their work unit a failing grade in global safety; 2 said it was poor; $39.2 \%(n=40)$ said it was acceptable; $54.9 \%(n=56)$ rated it very good; and $2.9 \%(n=3)$ said it was excellent. Most of the respondents $(80.1 \%, n=81)$ had not reported any unsafe events in previous 12 months; $14.9 \%(n=15)$ had reported $1-2$ incidents; and $5 \%(n=5)$ had reported $3-5$.

The mean percentage of positive responses ranged from $35.1 \%$ ("Nonpunitive response to errors") to $72.3 \%$ ("Teamwork within units") (Table 4). The dimensions computed as simple means (on a scale of $1-5$ ) were similar to the distribution of the mean percentages of positive re- sponses. The results from these 2 methods (Table 4) were highly correlated $(r=0.89 ; t=6.30 ; p<0.0001)$.

Cronbach's $\alpha$ scores (Table 4) ranged from 0.37 to 0.89 . Only 4 dimensions received reliability scores above 0.70 . Based on the Cronbach's $\alpha$ calculations, the author established that when question C6 was deleted from the "Communication openness" dimension, the score increased from 0.38 to 0.43 ; when question $\mathrm{F} 4$ was deleted from the "Teamwork across units" dimension, the score increased from 0.42 to 0.57; when question A7 was deleted from the "Staffing" dimension, the score increased from 0.45 to 0.55; and when question F11 was deleted from the "Handoffs \& transitions" dimension, the score increased from 0.47 to 0.50 .

In the case of the "Safety grade" (a single-item outcome variable), 7 out of 10 safety process dimension scores were significantly higher among respondents from the "excellent" or "very good" group vs the rest. The effect size ranged from 0.21 to 0.37 (small and mediumsize effect). In the case of "Reported an incident in the past 12 months" (another single-item outcome variable), 8 out of 10 safety process dimension scores were nonsignificant and only 2 dimension scores were significant ("Organizational learning - continuous improvement" and "Handoffs \& transitions"); surprisingly, in the case of "Handoffs \& transitions" dimension, in such a way that in this dimension the higher score was given by respondents who have not reported adverse events in the last 12 months (Table 5).

\section{Discussion}

This pilot study provided basic information about the Polish-language version of the HSOPSC questionnaire. ${ }^{5}$ Based on Cronbach's $\alpha$, the internal consistency of the Polish-language version was much lower than the original US version, ${ }^{5}$ many other European versions $s^{1,7-12}$ and the Chinese version..$^{13}$ The degree to which the questionnaire is comprehensible and easy to fill out for respondents in a Polish hospital setting was assessed with the response rate, which was high (88\%). The response rate in this study was higher than in studies of versions of the questionnaire used in France (74\%), Scotland (22\%), Norway (55\%), the USA (55\%), and China (77\%). ${ }^{1,5,7,10,13}$ However, both the response rate and the Cronbach's $\alpha$ data were from only 1 hospital, which may affect both the high response rate and low Cronbach's $\alpha$. A low Cronbach's $\alpha$ coefficient does not necessarily mean poor reliability, ${ }^{1}$ so it is worth assessing the test-retest reliability coefficient of the questionnaire in a larger study.

The mean scores of the process dimensions in subgroups of respondents - those who rated the safety grade "very good" or "excellent" as opposed to "good", "fair" or "poor", and those who had reported at least 1 incident in the previous 12 months as opposed to those who had not 
Table 1. Polish-language version of questions from the original HSOPSC questionnaire (42 items)

Tabela 1. Polska wersja językowa pytań z oryginalnego (anglojęzycznego) kwestionariusza HSOPSC (42 pytania)

\begin{tabular}{|c|c|c|}
\hline Item & PL/USA & Contents of question \\
\hline \multirow{2}{*}{ A1 } & $\mathrm{PL}$ & Ludzie pomagają sobie nawzajem w moim miejscu pracy. \\
\hline & USA & People support one another in this unit. \\
\hline \multirow{2}{*}{ A2 } & $\mathrm{PL}$ & Mamy wystarczającą liczbę pracowników w stosunku do obciążenia pracą. \\
\hline & USA & We have enough staff to handle the workload. \\
\hline \multirow{2}{*}{ A3 } & $\mathrm{PL}$ & Kiedy mamy do wykonania dużo czynności wymagających szybkiej interwencji, to potrafimy pracować jak zespół. \\
\hline & USA & When a lot of work needs to be done quickly, we work together as a team to get the work done. \\
\hline \multirow{2}{*}{ A4 } & $\mathrm{PL}$ & W tym oddziale ludzie traktują się wzajemnie z szacunkiem. \\
\hline & USA & In this unit, people treat each other with respect. \\
\hline \multirow{2}{*}{ A5 } & $\mathrm{PL}$ & Pracownicy pracują po godzinach pracy tak długo, że może to być ze szkodą dla pacjenta. \\
\hline & USA & Staff in this unit work longer hours than is best for patient care. \\
\hline \multirow{2}{*}{ A6 } & $P L$ & Aktywnie działamy na rzecz poprawy bezpieczeństwa pacjenta. \\
\hline & USA & We are actively doing things to improve patient safety. \\
\hline \multirow[t]{2}{*}{ A7 } & $\mathrm{PL}$ & $\begin{array}{l}\text { Zatrudnionych jest więcej pracowników tymczasowych i/lub z firm zewnętrznych niż jest to konieczne dla zapewnienia pacjentowi } \\
\text { możliwie najlepszej opieki. }\end{array}$ \\
\hline & USA & We use more agency/temporary staff than is best for patient care. \\
\hline \multirow{2}{*}{ A8 } & $\mathrm{PL}$ & Pracownicy są przekonani, że ich błędy są lub będą wykorzystane przeciwko nim. \\
\hline & USA & Staff feel like their mistakes are held against them. \\
\hline \multirow{2}{*}{ A9 } & $P L$ & Zaistniałe błędy doprowadziły do pozytywnych zmian. \\
\hline & USA & Mistakes have led to positive changes here. \\
\hline \multirow{2}{*}{ A10 } & $P L$ & To czysty przypadek, że nie zdarzają się tu poważne błędy. \\
\hline & USA & It is just by chance that more serious mistakes don't happen around here. \\
\hline \multirow{2}{*}{ A11 } & $\mathrm{PL}$ & Kiedy jakaś część oddziału jest bardziej obciążona praca, pracownicy z pozostałych części pomagają się z nią uporać. \\
\hline & USA & When one area in this unit gets really busy, others help out. \\
\hline \multirow[t]{2}{*}{$\mathrm{A} 12$} & $\mathrm{PL}$ & $\begin{array}{l}\text { Kiedy raportowane jest zdarzenie niepożądane, to ma się odczucie, jakby to wina danej osoby była ważniejsza niż treść i okoliczności } \\
\text { samego zdarzenia. }\end{array}$ \\
\hline & USA & When an event is reported, it feels like the person is being written up, not the problem. \\
\hline \multirow{2}{*}{ A13 } & $P L$ & Po wprowadzeniu zmian mających na celu poprawę oceniamy ich skuteczność. \\
\hline & USA & After we make changes to improve patient safety, we evaluate their effectiveness. \\
\hline \multirow{2}{*}{ A14 } & PL & Pracujemy w „trybie kryzysowym” - próbujemy wykonać zbyt wiele zadań i zbyt szybko. \\
\hline & USA & We work in "crisis mode" trying to do too much too quickly. \\
\hline \multirow{2}{*}{ A15 } & $\mathrm{PL}$ & Nigdy nie wykonujemy większej liczby zadań kosztem bezpieczeństwa pacjenta. \\
\hline & USA & Patient safety is never sacrificed to get more work done. \\
\hline \multirow{2}{*}{ A16 } & $\mathrm{PL}$ & Pracownicy niepokoją się tym, że informacje o błędach przechowywane są w ich aktach. \\
\hline & USA & Staff worry that mistakes they make are kept in their personnel file. \\
\hline \multirow{2}{*}{ A17 } & $P L$ & Występują u nas problemy z zapewnieniem bezpieczeństwa pacjentom. \\
\hline & USA & We have patient safety problems in this unit. \\
\hline \multirow{2}{*}{ A18 } & $\mathrm{PL}$ & Nasze procedury i organizacja pracy skutecznie zapobiegają występowaniu błędów. \\
\hline & USA & Our procedures and systems are good at preventing errors from happening. \\
\hline \multirow{2}{*}{ B1 } & $\mathrm{PL}$ & Przełożony/kierownik chwali nas za pracę wykonaną zgodnie z procedurami dotyczącymi bezpieczeństwa pacjentów. \\
\hline & USA & My supervisor/manager says a good word when he/she sees a job done according to established patient safety procedures. \\
\hline \multirow{2}{*}{ B2 } & PL & Przełożony/kierownik poważnie rozważa nasze sugestie dotyczące bezpieczeństwa pacjenta. \\
\hline & USA & My supervisor/manager seriously considers staff suggestions for improving patient safety. \\
\hline \multirow[t]{2}{*}{ B3 } & $\mathrm{PL}$ & $\begin{array}{l}\text { W trudnych sytuacjach przełożony/kierownik wymaga od nas, abyśmy pracowali szybciej, nawet jeśli oznaczałoby to „pójście na } \\
\text { skróty”. }\end{array}$ \\
\hline & USA & Whenever pressure builds up, my supervisor/manager wants us to work faster, even if it means taking shortcuts. \\
\hline \multirow{2}{*}{ B4 } & $P L$ & $\begin{array}{l}\text { Przełożonemu/kierownikowi zdarza się przymykać oczy na problemy związane z bezpieczeństwem pacjentów, mimo że powtarzają } \\
\text { się one „w kółko”. }\end{array}$ \\
\hline & USA & My supervisor/manager overlooks patient safety problems that happen over and over. \\
\hline
\end{tabular}


Table 1 cont. Polish-language version of questions from the original HSOPSC questionnaire (42 items)

Tabela 1 cd. Polska wersja językowa pytań z oryginalnego (anglojęzycznego) kwestionariusza HSOPSC (42 pytania)

Items $\mid$ PL/USA $\quad$ Contents of question

\begin{tabular}{|c|c|c|}
\hline \multirow{2}{*}{$\mathrm{C} 1$} & PL & Jesteśmy informowani o zmianach wdrożonych w odpowiedzi na zgłaszane zdarzenia niepożądane. \\
\hline & USA & We are given feedback about changes put into place based on event reports. \\
\hline \multirow{2}{*}{ C2 } & PL & Personel bez ogródek wyraża swoją opinię, jeśli dostrzeże, że coś może negatywnie wpłynąć na opiekę nad pacjentem. \\
\hline & USA & Staff will freely speak up if they see something that may negatively affect patient care. \\
\hline \multirow{2}{*}{ C3 } & $\mathrm{PL}$ & Jesteśmy informowani o błędach zaistniałych w naszym oddziale. \\
\hline & USA & We are informed about errors that happen in this unit. \\
\hline \multirow{2}{*}{ C4 } & $\mathrm{PL}$ & Personel czuje się swobodnie w kwestionowaniu decyzji lub działań zwierzchników. \\
\hline & USA & Staff feel free to question the decisions or actions of those with more authority. \\
\hline \multirow{2}{*}{ C5 } & $\mathrm{PL}$ & W naszym oddziale dyskutujemy na temat możliwych rozwiązań zaistniałych błędów w celu niedopuszczenia do nich w przyszłości. \\
\hline & USA & In this unit, we discuss ways to prevent errors from happening again. \\
\hline \multirow{2}{*}{ C6 } & $\mathrm{PL}$ & Obawiamy się zadawać pytania w sytuacji, gdy wydaje się nam, że coś jest nie tak jak powinno. \\
\hline & USA & Staff are afraid to ask questions when something does not seem right. \\
\hline \multirow{2}{*}{ D1 } & $\mathrm{PL}$ & $\begin{array}{l}\text { Jak często zgłasza się błędy, które choć popełniono, ale ze względu na to, że zostały w porę zauważone i skorygowane, nie wyrządziły } \\
\text { szkody pacjentowi? }\end{array}$ \\
\hline & USA & When a mistake is made, but is caught and corrected before affecting the patient, how often is this reported? \\
\hline \multirow{2}{*}{ D2 } & $\mathrm{PL}$ & $\begin{array}{l}\text { Jak często zgłaszane są popełnione błędy, które nie mają potencjalnego wpływu na powstanie szkody } \\
\text { u pacjenta? }\end{array}$ \\
\hline & USA & When a mistake is made, but has no potential to harm the patient, how often is this reported? \\
\hline \multirow{2}{*}{ D3 } & $\mathrm{PL}$ & $\begin{array}{l}\text { Jak często zgłaszane są popełnione błędy, które z dużym prawdopodobieństwem mogłyby spowodować szkodę u pacjenta, jednak } \\
\text { tym razem jej nie spowodowały? }\end{array}$ \\
\hline & USA & When a mistake is made that could harm the patient, but does not, how often is this reported? \\
\hline \multirow{2}{*}{ E } & $\mathrm{PL}$ & Proszę oceń stopień zapewnienia bezpieczeństwa pacjentowi w swoim miejscu pracy/oddziale/klinice. \\
\hline & USA & Please give your work area/unit in this hospital an overall grade on patient safety. \\
\hline \multirow{2}{*}{ F1 } & $P L$ & Dyrekcja szpitala tworzy atmosferę pracy, która sprzyja bezpieczeństwu pacjenta. \\
\hline & USA & Hospital management provides a work climate that promotes patient safety. \\
\hline \multirow{2}{*}{ F2 } & $\mathrm{PL}$ & Współpraca pomiędzy oddziałami w szpitalu nie jest odpowiednio skoordynowana. \\
\hline & USA & Hospital units do not coordinate well with each other. \\
\hline \multirow{2}{*}{ F3 } & $\mathrm{PL}$ & Kiedy pacjentów przenosi się między oddziałami, zdarza się że niektóre sprawy „umykają uwadze”. \\
\hline & USA & Things "fall between the cracks" when transferring patients from one unit to another. \\
\hline \multirow{2}{*}{ F4 } & $\mathrm{PL}$ & Współpraca jest dobra pomiędzy tymi oddziałami, które ze względu na swój profil muszą współpracować. \\
\hline & USA & There is good cooperation among hospital units that need to work together. \\
\hline \multirow{2}{*}{ F5 } & $\mathrm{PL}$ & Ważne informacje na temat opieki nad pacjentem często nie są przekazywane podczas zdawania dyżuru. \\
\hline & USA & Important patient care information is often lost during shift changes. \\
\hline \multirow{2}{*}{ F6 } & $\mathrm{PL}$ & Współpraca z personelem z innych oddziałów szpitala często pozostawia wiele do życzenia. \\
\hline & USA & It is often unpleasant to work with staff from other hospital units. \\
\hline \multirow{2}{*}{ F7 } & $\mathrm{PL}$ & Często zdarzają się problemy z wymianą informacji pomiędzy różnymi oddziałami szpitala. \\
\hline & USA & Problems often occur in the exchange of information across hospital units. \\
\hline \multirow{2}{*}{ F8 } & $\mathrm{PL}$ & Działania dyrekcji szpitala pokazują, że bezpieczeństwo pacjenta jest głównym priorytetem. \\
\hline & USA & The actions of hospital management show that patient safety is a top priority. \\
\hline \multirow[t]{2}{*}{ F9 } & $\mathrm{PL}$ & $\begin{array}{l}\text { Dyrekcja szpitala wydaje się być zainteresowana bezpieczeństwem pacjenta dopiero wtedy, gdy dojdzie do zdarzenia } \\
\text { niepożądanego. }\end{array}$ \\
\hline & USA & Hospital management seems interested in patient safety only after an adverse event happens. \\
\hline \multirow{2}{*}{ F10 } & PL & Oddziały w szpitalu dobrze współpracują między sobą, aby zapewnić pacjentowi najlepszą możliwą opiekę. \\
\hline & USA & Hospital units work well together to provide the best care for patients. \\
\hline \multirow{2}{*}{ F11 } & $\mathrm{PL}$ & Przekazywanie dyżuru następnej zmianie stwarza problemy dla pacjentów. \\
\hline & USA & Shift changes are problematic for patients in this hospital. \\
\hline \multirow[t]{2}{*}{ G } & PL & $\begin{array}{l}\text { lle raportów dotyczących zdarzeń niepożądanych w ostatnich } 12 \text { miesiącach zostało przez ciebie opisanych i zgłoszonych osobiście/ } \\
\text { pisemnie (anonimowo lub jawnie/imiennie)? }\end{array}$ \\
\hline & USA & In the past 12 months, how many event reports have you filled out and submitted? \\
\hline
\end{tabular}

$\mathrm{PL}$ - Polish version; USA - original AHRQ version. 
Table 2. Characteristics of the respondents

Tabela 2. Charakterystyka respondentów

\begin{tabular}{|c|c|c|c|c|c|}
\hline Item & PL/USA & Contents of question & Answer & $n$ & $\%$ \\
\hline \multirow{7}{*}{$\mathrm{H} 1$} & \multirow{4}{*}{$\mathrm{PL}$} & \multirow{4}{*}{$\begin{array}{l}\text { Jak długo pracujesz w szpitalu, w którym } \\
\text { wręczono Ci tę ankietę? }\end{array}$} & less than 1 year & 4 & 3.9 \\
\hline & & & 1 to 5 years & 3 & 2.9 \\
\hline & & & 6 to 10 years & 7 & 6.9 \\
\hline & & & 11 to 15 years & 4 & 3.9 \\
\hline & \multirow{3}{*}{ USA } & \multirow{3}{*}{ How long have you worked in this hospital? } & 16 to 20 years & 10 & 9.8 \\
\hline & & & 21 years or more & 74 & 72.5 \\
\hline & & & total & 102 & 100.0 \\
\hline \multirow{7}{*}{$\mathrm{H} 2$} & \multirow{3}{*}{$\mathrm{PL}$} & \multirow{4}{*}{$\begin{array}{l}\text { Jak długo pracujesz w obecnym miejscu pracy, } \\
\text { w którym wręczono Ci ankietę } \\
\text { - oddziale/klinice? }\end{array}$} & less than 1 year & 4 & 3.9 \\
\hline & & & 1 to 5 years & 5 & 4.9 \\
\hline & & & 6 to 10 years & 19 & 18.6 \\
\hline & \multirow{4}{*}{ USA } & & 11 to 15 years & 11 & 10.8 \\
\hline & & \multirow{3}{*}{$\begin{array}{l}\text { How long have you worked in your current } \\
\text { hospital work area/unit? }\end{array}$} & 16 to 20 years & 10 & 9.8 \\
\hline & & & 21 years or more & 53 & 52.0 \\
\hline & & & total & 102 & 100.0 \\
\hline \multirow{7}{*}{$\mathrm{H3}$} & \multirow{4}{*}{$\mathrm{PL}$} & \multirow{4}{*}{$\begin{array}{l}\text { Średnio ile godzin tygodniowo pracujesz } \\
\text { w tym szpitalu, w którym wręczono Ci ankietę? }\end{array}$} & less than $20 \mathrm{~h}$ per week & 0 & 0.0 \\
\hline & & & 20 to 39 h per week & 48 & 47.5 \\
\hline & & & 40 to 59 h per week & 48 & 47.5 \\
\hline & & & 60 to $79 \mathrm{~h}$ per week & 3 & 3.0 \\
\hline & \multirow{3}{*}{ USA } & \multirow{3}{*}{$\begin{array}{l}\text { Typically, how many hours per week do you } \\
\text { work in this hospital? }\end{array}$} & 80 to 99 h per week & 1 & 1.0 \\
\hline & & & $100 \mathrm{~h}$ per week or more & 1 & 1.0 \\
\hline & & & total & 101 & 100.0 \\
\hline \multirow{7}{*}{$\mathrm{H} 4$} & \multirow{4}{*}{$\mathrm{PL}$} & \multirow{4}{*}{$\begin{array}{l}\text { Jaka jest Twoja pozycja zawodowa w szpitalu, } \\
\text { w którym wręczono Ci ankietę? Wybierz } \\
\text { JEDNĄ odpowiedź najlepiej opisującą Twoją } \\
\text { pozycję zawodową. }\end{array}$} & nurse - non-university education & 33 & 32.4 \\
\hline & & & Bachelor of Nursing or Master of Nursing & 50 & 49.0 \\
\hline & & & nurse with specialization & 3 & 2.9 \\
\hline & & & midwife - vocational secondary education & 4 & 3.9 \\
\hline & \multirow{3}{*}{ USA } & \multirow{3}{*}{$\begin{array}{l}\text { What is your staff position in this hospital? } \\
\text { Select ONE answer that best describes your } \\
\text { staff position. }\end{array}$} & Bachelor of Midwifery or Master of Midwifery & 10 & 9.8 \\
\hline & & & midwife with specialization & 2 & 2.0 \\
\hline & & & total & 102 & 100.0 \\
\hline \multirow{4}{*}{ H5 } & \multirow{2}{*}{$\mathrm{PL}$} & \multirow{2}{*}{$\begin{array}{l}\text { Ze względu na swoją pozycję zawodową } \\
\text { w tym szpitalu, w którym wręczono Ci ankietę, } \\
\text { czy masz zazwyczaj bezpośredni kontakt } \\
\text { z pacjentem? }\end{array}$} & $\begin{array}{l}\text { YES, I typically have direct interaction or } \\
\text { contact with patients }\end{array}$ & 92 & 92.8 \\
\hline & & & $\begin{array}{l}\text { NO, I typically do NOT have direct interaction } \\
\text { or contact with patients }\end{array}$ & 7 & 7.2 \\
\hline & \multirow[t]{2}{*}{ USA } & \multirow{2}{*}{$\begin{array}{l}\text { In your staff position, do you typically have } \\
\text { direct interaction or contact with patients? }\end{array}$} & & & \\
\hline & & & total & 101 & 100.0 \\
\hline \multirow{7}{*}{ H6 } & & & less than 1 year & 3 & 3.0 \\
\hline & $\mathrm{PL}$ & Jak długo pracujesz w obecnym zawodzie? & 1 to 5 years & 1 & 1.0 \\
\hline & & & 6 to 10 years & 4 & 4.0 \\
\hline & & & 11 to 15 years & 2 & 2.0 \\
\hline & & & 16 to 20 years & 9 & 8.0 \\
\hline & USA & specialty or profession? & 21 years or more & 83 & 82.0 \\
\hline & & & total & 102 & 100.0 \\
\hline
\end{tabular}

- show a low level of construct validation. In terms of the safety grade ratings, 7 out of 10 dimensions proved to be statistically significant ( $p$-value $0.05-0.001$ ) with small and medium Cohen's $d$ effect sizes (0.21-0.37). The 3 dimensions that lacked statistical significance were "Nonpunitive response to errors", "Handoffs \& transitions" and "Staffing". In the case of "Nonpunitive response to errors", despite the insignificant result, the score was higher among those respondents who rated safety "good", "fair" or "poor" than among those who rated it "excellent" or "very good". Overall, this is not a bad result but it does not inspire enthusiasm in terms of the construct valida- 
Table 3. Type of work area

Tabela 3. Oddziały, na których pracują respondenci

\begin{tabular}{|l|c|c|}
\hline Type of ward & $n$ & $\%$ \\
\hline Obstetrics & 15 & 14.6 \\
$\begin{array}{l}\text { Intensive care unit } \\
\text { (any type) }\end{array}$ & 14 & 13.6 \\
General surgery & 13 & 12.6 \\
Orthopedic surgery & 11 & 10.7 \\
Pediatrics & 10 & 9.7 \\
Neonatology & 10 & 9.7 \\
Internal medicine & 10 & 9.7 \\
Cardiology & 6 & 5.8 \\
Many different hospital units & 5 & 4.9 \\
or no specific unit & & \\
Operating block & 5 & 4.9 \\
\hline Hospital emergency ward & 3 & 2.9 \\
Nurse management & 1 & 1.0 \\
\hline Total & 103 & 100.0 \\
\hline
\end{tabular}

tion of the survey. The situation is even worse when looking at respondents who had or had not reported incidents in the previous 12 months. Only 2 out of 10 dimensions - "Handoffs \& transitions" and "Organizational learning/ Continuous improvement" - proved to be statistically significant ( $p$-values 0.05 and 0.04 , respectively) with small and medium Cohen's $d$ effects $(0.25$ and 0.37 , respectively). Other dimensions have failed in achieve statistical significance. Furthermore, in the case of "Handoffs \& transitions", the result was the opposite of the expected outcome: The respondents who had reported incidents had lower scores, not higher ones. It is worth mentioning that similar results can be found in other studies. ${ }^{5,11,14}$ For this reason, other authors suggested that incident-reporting behavior should not be used for construct validation. ${ }^{5}$

When it comes to recommendations for the management of the hospital under consideration in the study, it can be said that efforts to improve patient safety are particularly needed in the 4 dimensions that received the lowest score from the respondents: "Nonpunitive re-

Table 4. Descriptive statistics and results of reliability analysis of 12 dimensions of the questionnaire

Tabela 4. Statystyka opisowa oraz wyniki analizy rzetelności poszczególnych wymiarów kwestionariusza

\begin{tabular}{|c|c|c|c|c|c|c|c|c|c|}
\hline \multirow{2}{*}{ Dimensions } & \multirow{2}{*}{$\begin{array}{l}\text { Number } \\
\text { of item }\end{array}$} & \multicolumn{2}{|c|}{ Missing data } & \multicolumn{2}{|c|}{$\begin{array}{l}\text { Percentage } \\
\text { of positive } \\
\text { responses }\end{array}$} & \multicolumn{2}{|c|}{$\begin{array}{l}\text { Mean score } \\
\quad(1-5)\end{array}$} & \multirow{2}{*}{$\begin{array}{l}\text { Cronbach's a } \\
\text { reliability }\end{array}$} & \multirow{2}{*}{$\begin{array}{l}\text { Correlation } \\
\text { between } \\
\text { the percentage } \\
\text { of positive } \\
\text { responses } \\
\text { and mean } \\
\text { score }\end{array}$} \\
\hline & & $n$ & $\%$ & $M$ & $S D$ & M & $S D$ & & \\
\hline Teamwork within units & 4 & 6 & 1.5 & 72.3 & 15.7 & 3.70 & 0.91 & 0.73 & \multirow{12}{*}{$\begin{array}{c}r=0.89 \\
t=6.30 \\
p<0.0001\end{array}$} \\
\hline $\begin{array}{l}\text { Supervisor/manager expectations \& } \\
\text { actions promoting patient safety }\end{array}$ & 4 & 5 & 1.2 & 65.6 & 13.5 & 3.59 & 0.84 & 0.73 & \\
\hline $\begin{array}{l}\text { Organizational learning - continuous } \\
\text { improvement }\end{array}$ & 3 & 11 & 3.6 & 67.1 & 16.3 & 3.58 & 0.85 & 0.38 & \\
\hline Management support for patient safety & 3 & 7 & 2.3 & 44.7 & 7.2 & 3.20 & 0.98 & 0.68 & \\
\hline Overall perceptions of patient safety & 4 & 11 & 2.7 & 54.1 & 8.8 & 3.36 & 0.99 & 0.50 & \\
\hline $\begin{array}{l}\text { Feedback \& communication about } \\
\text { errors }\end{array}$ & 3 & 11 & 3.6 & 69.5 & 3.4 & 4.02 & 1.01 & 0.84 & \\
\hline Communication openness & 3 & 9 & 2.9 & 53.3 & 16.3 & 3.56 & 1.07 & $\begin{array}{c}0.38 \\
\text { (delete C6 } \\
\text { then 0.43) }\end{array}$ & \\
\hline Frequency of events reported & 3 & 12 & 3.9 & 53.5 & 7.9 & 3.53 & 1.27 & 0.89 & \\
\hline Teamwork across units & 4 & 10 & 2.4 & 44.5 & 19.0 & 3.21 & 0.80 & $\begin{array}{c}0.42 \\
\text { (delete F4 } \\
\text { then 0.57) }\end{array}$ & \\
\hline Staffing & 4 & 16 & 3.9 & 50.7 & 31.3 & 3.17 & 1.01 & $\begin{array}{c}0.45 \\
\text { (delete A7 } \\
\text { then 0.55) }\end{array}$ & \\
\hline Handoffs \& transitions & 4 & 8 & 1.9 & 62.4 & 28.4 & 3.53 & 0.82 & $\begin{array}{c}0.47 \\
\text { (delete F11 } \\
\text { then 0.50) }\end{array}$ & \\
\hline $\begin{array}{l}\text { Nonpunitive response } \\
\text { to errors }\end{array}$ & 3 & 7 & 2.3 & 35.1 & 7.4 & 2.92 & 1.06 & 0.61 & \\
\hline
\end{tabular}

$n$ - sample size; $M$ - mean; SD - standard deviation. 
sponse to errors" (average 2.92 points on a scale of 1-5), "Staffing" (average 3.17 points), "Management support for patient safety" (3.20 points), and "Teamwork across units" (3.21 points). The 2 highest scores were given to "Feedback \& communication about errors" (4.02) and "Teamwork within units" (3.70). To sum up, it can be said that the hospital in the study had not established a culture and climate of reporting adverse events, and that there is a problem with insufficient staff. From the author's experience, these 2 problems are typical of most if not all hospitals in Poland.

Considering the limitations of this study, 3 things should be said. Firstly, this study was conducted in only 1 multi-site hospital, which may affect the value of the results, especially in terms of construct validation, which is why the author did not carry out a full psychometric analysis. It is worth mentioning that the author's attention was focused on the grammatical and logical correctness of the questions, and also on the response rate, both of which proved to be strong points of this study. Secondly, there is no data about the non-respondents, which may affect the results of the study. However, $12 \%$ non-response rate is not a high percentage. Thirdly, this study was conducted during at a single time period, and it would be worthwhile to perform the investigation on the same respondents over time (test-retest) to show the real reliability coefficient for the Polish-language version of the HSOPSC.

\section{Conclusions}

The Polish-language version of the HSPOSC - ASBP - is less psychometrically sound than the English-language original. The internal consistency (Cronbach's $\alpha$ ) of the ASBP is even lower than many European versions of the HSOPSC. This pilot study provided evidence that the logical and grammatical construction of translated questions is comprehensible for Polish respondents, which provides grounds for the use of the Polish-language version in a study involving a larger population of health workers in Poland in order to fully assess the psychometric properties of the ASBP.

\section{ORCID iD}

Rafał Szpakowski ำ https://orcid.org/0000-0003-3820-8950

\section{References}

1. Perneger TV, Staines A, Kundig F. Internal consistency, factor structure and construct validity of the French version of the Hospital Survey on Patient Safety Culture. BMJ Qual Saf. 2014;23(5):389-397. doi:10.1136/bmjqs-2013-002024

2. The Health Foundation. Measuring Safety Culture. February 2011. http://www.health.org.uk/sites/default/files/MeasuringSafetyCulture.pdf. Accessed on July 7, 2019.

3. Arain M, Campbell MJ, Cooper CL, Lancaster GA. What is a pilot or feasibility study? A review of current practice and editorial policy. BMC Med Res Methodol. 2010;10:67. doi:10.1186/1471-2288-10-67

4. Fan W, Yan Z. Factors affecting response rates of the web survey: A systematic review. Comput Human Behav. 2010;26(2):132-139. doi:10.1016/j.chb.2009.10.015

5. Sorra JS, Dyer N. Multilevel psychometric properties of the AHRQ hospital survey on patient safety culture. BMC Health Serv Res. 2010;10:199. doi:10.1186/1472-6963-10-199

6. Sorra J, Gray L, Streagle S, et al. AHRQ Hospital Survey on Patient Safety Culture: User's Guide. http://www.ahrq.gov/professionals /quality-patient-safety/patientsafetyculture/hospital/index.html. Accessed on July 7, 2019.

7. Sarac C, Flin R, Mearns K, Jackson J. Hospital survey on patient safety culture: Psychometric analysis on a Scottish sample. BMJ Qual Saf. 2011;20(10):842-848. doi:10.1136/bmjqs.2010.047720

8. Smits M, Dingelhoff IC, Wagner C, Wal Gv, Groenewegen PP. The psychometric properties of the 'Hospital Survey on Patient Safety Culture' in Dutch hospitals. BMC Health Serv Res. 2008;8:230. doi:10.1186/1472-6963-8-230

9. Robida A. Hospital Survey on Patient Safety Culture in Slovenia: A psychometric evaluation. Int J Qual Health Care. 2013;25(4):469-475. doi:10.1093/intqhc/mzt040

10. Olsen E. Reliability and validity of the hospital survey on patient safety culture at a Norwegian hospital. In: Øvretveit J, Sousa P, eds. Quality and Safety Improvement Research. Lisbon, Portugal: National School of Public Health; 2008:173-186.

11. Pfeiffer Y, Manser T. Development of the German version of the hospital survey on patient safety culture: Dimensionality and psychometric properties. Saf Sci. 2010;48(10):1452-1462. doi:10.1016/j .ssci.2010.07.002

12. Waterson PE, Griffiths P, Stride C, Murphy J, Hignett S. Psychometric properties of the hospital survey on patient safety: Findings from the UK. Qual Saf Health Care. 2010;19(5):e2. doi:10.1136 /qshc.2008.03162

13. Nie $Y$, Mao X, Cui H, He S, Li J, Zhang M. Hospital survey on patient safety culture in China. BMC Health Serv Res. 2013;13:228. doi:10.1186/1472-6963-13-228

14. El-Jardali F, Dimassi H, Jamal D, Jaafar M, Hemadeh N. Predictors and outcomes of patient safety culture in hospitals. BMC Health Serv Res. 2011;11:45. doi:10.1186/1472-6963-11-45 